Research Article

\title{
Communicative Competence in Mlayokaken Tradition of Banyuwangi "Using" Community
}

\author{
Akhmad Haryono \\ Faculty of Culture Science, University of Jember Jl. Kalimantan, 37 Kampus Tegalboto Jember, Jawa \\ Timur, Indonesia
}

\begin{abstract}
Melayokaken' which means abducting a woman who has been loved by a man but they are not approved by the woman's parents. The tradition takes place among Banyuwangi Using community (BUC) that has been going on for long time from generation to generation. This event can certainly make a conflict among families and in the community. In general, this study aims at exploring and describing the communicative competence in melayokaken tradition. In particular, it will explore the linguistic knowledge that is used by melayokaken actors; the application of interaction skill used by the actors involved in the melayokaken tradition; the cultural knowledge applied in melayokaken tradition. The method used to achieve the research objectives is qualitative method, with the focus on ethnographic study of communication. The data collected through participant observation, interview, and recording are transcribed into written data and then analyzed by using speech component analysis with communication ethnography method. The study result finds that the communicative competence possessed by the people involved in melayokaken tradition (the young man abducting, the abducted woman, the woman's parents, the man's parents, and the mediator called colok) can be well categorized from the linguistic knowledge, interaction skills, and cultural knowledge in the process of melayokaken tradition. From this finding, it is very important for the people involved in melayokaken tradition, especially for the colok, to have these communicative competence features because communicative competence can determine a person's pattern and strategy of communication, so that the conflict among Using community will not happen.
\end{abstract}

Key words: communicative competence, melayokaken, Using

\section{Background}

The structure of "Using" language is parallel to the social structure of "Using" community. Social structure is a system of social interaction based on the position and status of the people involved in it. That status and role will reflect the patterns of rights and obligations of each of the people involved. The social structure of "Using" community is also related to the history or historical elements of the formation of "Using" (Haryono, 2017) community. The social structure of "Using" community is egalitarian (Saputra, 2008). Therefore, as a sense of pride and ownership of "Using" people, they justify "Using" community is not a Javanese ethnic subgroup, but a distinct ethnic group that is "Using" ethnic group (Haryono, 2014).

'Melayokaken', which means to abduct a woman who is loved by a man without the approval of the woman's parents in Banyuwangi Using Community (BUC), is a long-standing tradition from generation to generation (Haryono, 2017). As written in Saputra (2007), it is often found in the lives of people who are less respectful of the parent's role, as reflected by the existence of melayoaken or colongan culture (ie, shortcuts to marriage by the way that a youth abducts his sweatheart because their amour relationship is not approved by the woman's parents.)

The tradition of melayokaken often causes the conflict between the two families (the man's side and the woman's side) in BUC. Anticipating and resolving the conflict

certainly needs communicative competence of colok (the mediator provided by the parents of man) as well as both parties involved in melayokaken (Haryono, 2017).

Communicative competence is a person's ability to communicate in conveying his/her ideas to others. It involves knowledge not only of the language code, but also what to say to whom, and how to say it correctly in certain situations. It deals with the social and cultural knowledge that speakers have to help them use and interpret linguistic forms (Haryono, 2015). Communicative competence can determine a person's communication patterns.

Communication patterns are models of the interaction of language use by using certain speech codes, which are influenced by the distinctive and recurrent relationships between the speech components (Kuswarno, 2008). Further (Haryono, 2014, 2018) defines that communication patterns can constitute category and function of language reflected in speech, use of speech level, choice of language and variety of languages as a form of code switching and code mixing, intonation (tone), and symbols are displayed through body language as a supporting aspect in understanding speech acts that occur in verbal language, as well as transfer turn shift.

The uniqueness of Using community makes many experts interested in researching and writing about Using Studies on issues languages, arts, oral literature, anthropology and other 


\section{Akhmad Haryono / Communicative Competence in Mlayokaken Tradition of Banyuwangi "Using” Community}

studies. The Studies of Using focused on oral literature were conducted by Kusnadi (1993), Sugihartoyo (1993), Ali (1994), Sentot (1995), Sudjarwadi, et al. (1995), Saputra (1999), Marwoto, et al. (1999), and Marwoto and Saputra (2000). Among the Oral literature studies, which focus his study on the mantra are Kusnadi (1993), Sugihartoyo (1993), Sudjarwadi, et al. (1995), Saputra (1999), Marwoto, et al. (1999), and Marwoto and Saputra (2000). The following is briefly described using the Using mantra study.

Some of these studies focus on language, culture, and literature, whereas their association with socio-cultural backgrounds is less attention (except Kusnadi, 1993 and Saputra, 2007). As one of the cultural products, Melayokaken tradition is studied in a socio-cultural context because the study contains cultural values and worldviews against the community of Using. After the study of cultural anthropology finally understandable convention that happened in local culture. Nevertheless, there has been no anticipated and resolved resolution before the comprehensive review of its communication competence. Thus, the specific novelty of this study (which differs from previous studies) are two things: First, studies relating to previous Using societies have emphasized more on their language, culture, and oral literature in general, whereas this study more emphasis on communicative competence as a reflection of language skills, interaction skills, and cultural knowledge that occurs specifically in melayokaken tradition. Second, research on previous language studies using Sariono (2007) only emphasizes the choice of language in Kecamatan Singotrunan, but has not yet comprehensively addressed communicative competence specifically in melayokaken tradition.

Therefore, the orientation of this research is assumed to provide a new perspective on the study of Communication of Ethnography and Pragmatic, especially related to the Using community and at the same time is expected to be a reference for linguists, culturalists and anthropologists in subsequent studies related to the topic of Using community Banyuwangi. Based on these phenomena can be formulated the problem "How is the communicative competence of the parties involved in the Melayokaken tradition?"

\section{Communicative Competence}

Communicative Competence (CC) is the term used by Hymes (1972b) to show that speakers can produce grammatical sentences of a language based on the definition of linguistic competence by Chomsky (1965). It will be institutionalized if they try to do so (Hymes, 1982b).

Communicative competence involves knowledge not only of the language code, but also what to say to whom, and how to say it correctly in certain situations. Communicative competence deals with social and cultural knowledge that has speakers to help them use and interpret linguistic forms.

The fact that a normal child learns about the order of sentences, not just grammar, but also learns about the suitability of its use in a particular context. He learns the competence of when he speaks and when does not speak, and what is discussed, with whom, when, where, and how. In short, a child with the ability to speak to be able to communicate something to others, imitating songs, playing roles (roleplay) by imitating someone who acts as a doctor and patient, buyer and seller, and so on.

In addition, the $\mathrm{CC}$ is an inseparable part of attitudes, values, and motivations relating to language, its sides and uses, and can not be separated by competence to determine attitudes toward the interrelation of languages with codes and other symbols of communicative action (Hymes, 1972b: 277-278).

The discussion of communicative and linguistic competence (grammatical) usually ranges from two points: (1) the need to include grammatical description with appropriate conditions; (2) a balance between grammatical (or linguistic) code with other aspects such as body movement, eye gaze, and so on (Hymes, 1982b).

Communicative competence includes both knowledge and expectation about who can or can not speak in a particular setting, when to say it and when to keep silent, who to talk to, how one speaks to a person of different role status, which nonverbal behavior is appropriate for different what is the context, what routine happens to turn in conversation, how to offer help and cooperation, how to ask and give information, how to enforce discipline and so on (Ibrahim 1994)

In fact, the main difference between Chomsky and Hymes thinking about competence is: Chomsky rely on assumptions which states that science can be studied separately by action, interpreted as the implementation of that science in the use of language, whereas for Hymes, participation, appearance, and intersubjective science as a whole is a very important aspect as ai the ability to "know a language" (Saville-Troike, 1982 and 1984).

We all know that most of the work by Chomsky and his students is based on his ability to find (ie imagine) the appropriate context in spelling out certain types of speech. Although there are theoretical assumptions about certain aspects of grammar that are considered pure cognitive, the actual definition of such aspects lies in the possibility of combining sentences with the real world, which in turn is based on experience by linguists about the world in which they live (Garfinkel, 1967; Bleicher, 1982).

Communicative competence refers to the knowledge and skills for contextual use and interpretation of language in a community. Therefore, communicative competence refers to the knowledge and communicative skills shared by a particular group (like other aspects of a culture), although this varies greatly in group members involving different individuals. The nature of individual competence reflects the essence of the language itself. (Saville-Troike, 1982, 1989, and 2003)

Cross-cultural differences can and do generate conflicts or lead to communication failure. For example, issues such as sound levels may differ cross-culturally, and speakers' intentions can be misunderstood because of different interpretation expectations.

Therefore, communicative competence must be added in the concept of cultural competence, or the overall knowledge and skills brought in a situation. This view is consistent with the 


\section{Akhmad Haryono / Communicative Competence in Mlayokaken Tradition of Banyuwangi "Using” Community}

semiotic approach that defines culture as meaning, and sees all ethnographers associated with symbols (check Geertz, 1973; Doglas 1970). Thus it can be said that the cultural system is a symbolic pattern, and language is one of the symbol systems in this framework. The interpretation of linguistic meaning requires knowledge of the meaning in which the linguistic behavior is placed.

The following outline summarizes the range of knowledge that speakers need to have in order to communicate appropriately. From an ethnographer's perspective, it also shows the range of linguistic, interactional and cultural phenomena that should be given attention in an adequate description and explanation of communication. The following are the components of communication competence:

\section{Linguistic Knowledge}

a. Verbal elements;

b. Nonverbal elements;

c. Patterns of elements in a particular speech event;

d. Possible variant ranges (in all elements and the organization of those elements)

e. The meaning of variants in certain situations.

\section{Interaction skills}

a. Perception of essential characteristics in communicative situations;

b. Selection and interpretation of appropriate forms for specific situations, roles and relationships (rules for speech users);

c. Interaction norms and interpretations;

d. Strategies to achieve goals.

\section{Cultural knowledge}

a. Social structure

b. Value and attitude;

c. Map/cognitive scheme

d. The process of enkulturasi (transmission of knowledge and skills) (Saville-Troike 1982, 1989, 2003, Haryono, 2015)

From the above outline it can be abstracted that communicative competence refers to the knowledge and skills for the use and interpretation of contextually appropriate language in a community, then communicative on the knowledge and communicative skills shared by particular groups, although this varies in members individually.

\section{Research Method}

The approach used in this study is a qualitative approach with focus on the ethnographic study of communication and pragmatic. The ethnographic study of communication according to Kuswarno (2008) is a study that can describe, explain, and build relationships from the categories of data found. This is in line with the goal of ethnography of communication to analyze, describe, and explain the communication behavior of a socio-cultural group. The pragmatic is the study of the meaning desired by the speakers and which is accepted (interpreted) by the speakers (the participants of speech, the opponent of the speech, and the speech partner) by paying attention to the relationship with speech situations.

The technique used to enter the study site is a non-formal technique. This is done to maintain the authenticity of data obtained from the informants as well as from the observations directly in the field. To support the nonformal technique, the researcher's role in this research is closed, ie the researcher keeps his identity as a researcher, because the researcher acts as a intelligent. This is done to maintain the validity and authenticity of the data.

The location used in the implementation of this research is within the scope of Banyuwangi regency which in fact is inhabited most of Using people of. The district was chosen as a research location, because Using Community in the Regency is very dominant and the frequency of melayokaken tradition is still common.

Data will be obtained from three sources: first (primary) will be extracted from the direct observation of the communication process of the melayokaken actors and the people involved in it through participant observation; second (secondary) will be obtained from parents who are often involved in communication; third, information from religious leaders, community leaders, and scientists who pursue the ethnographic study of communication and pragmatic and the study of Using community.

The setting of communication to be investigated is when the informants communicate in informal situations. Informal situations, ie communication situations that occur in melayokaken outside the context of the formal situation, for example when they make a conspiracy, a conflict situation, when colok comes to reconcile the situation, and the like.

The observation of participation is done to obtain communication event data by observing, and recording directly research data. Researchers while participating with partners said that they are in the midst of melayokaken actor community and also directly involved in the activities of communication.

Interviews were conducted to obtain information about communication behavior and speech acts that were exhibited by the offender community melayokaken in real communication settings. Interview activities conducted by semi-directional, ie interviews conducted by using a list of questions that has been prepared by researchers, but has been memorized by researchers. The use of semi-directed interviews aims to make the study seem less formal so informants are not shy / giving as much information as possible to the researcher, without having to deviate from the main purpose of the research.

The recording activity, using a tape recorder or HP stored in a pocket. This activity is conducted to record the communication process and interview as a complement to overcome the limitations of the researcher in recording directly the communication process in participant observation and interview.

The recording activity is carried out to record data obtained from the field directly, in the sense that all data and information obtained in the field are recorded carefully on the 


\section{Akhmad Haryono / Communicative Competence in Mlayokaken Tradition of Banyuwangi "Using" Community}

same day. This activity is conducted with the intent to avoid the possibility of forgetting or overlapping data and also to overcome the loss of information obtained, either through participant observation or from informant research.

Data collected through participant observation, field notes, and recording devices, are transcribed into phonologically written data. Phonologically meaning of words in transcribed data is in accordance remarks raised by the subject of research and spelling rules in force in that language, so that the phonological features in the data can be displayed in the oral writes the data that has been in the transcript.

The data obtained in this research will be analyzed descriptively by the method of communication ethnography, discourse analysis method, and descriptive method. The ethnographic method of communication (see, Hymes (1972 a \& b), Schiffrin, 1994) was used to analyze patterns of communication used by marital offenders between ethnics, by conducting in-depth analysis of speech components used by citizens Using melayokaken in communicating with different speech partners, both in age and in family and in community. The analysis of the data includes the classification of speech component in the theory of communication ethnography proposed by Hymes (1972 a \& b); Schiffrin, 1994) known as the 'SPEAKING grid', ie (1) S (Situation/ 'setting': place and atmosphere); (2) $P$ (Participant) 'speech participants': speaker, intended, listener / recipient); (3) E (Ends 'end': results, speech objectives); (4) A (act sequence 'act speed': message form and message content); (5) K (key 'key'): Tone of speech; (6) I (instrumentalities: speech means); (7) N (norms 'norms': norms of interaction and interpretation); (8) G (genres 'style, flow'); Discourse analysis methods with the help of pragmatic concepts (see Brown \& Yule, 1996) are used to analyze communication strategies and factors that can lead to communication bottlenecks or failures by analyzing in depth the principle of cooperation (PC) and the principle of Politeness (PP) Grice (1999). PC includes four maxims, namely: Quality: Make a donation conversation right, Quantity: Make your conversational contribution as a possible information as required by the conversation. Do not make donations more informative than necessary. Relationship/relevance: Make your conversation relevant. Ways (Manner): Speak clearly, and in particular: 1) avoid blurring; 2) avoid coercion (double meaning); 4) speak briefly; 5) speak regularly.

There are two techniques that will be used to test the validity of the data are: (1)Triangulation, namely by comparing the two data from different informants, then taking the conclusion, whether the two data is different or mutually reinforce each other; (2) Verification is by way of checking directly to the field, whether the data have been obtained in accordance with the existing data in the field.

To obtain the level of confidence of the research results, the results of the research will be disseminated and discussed with the experts in accordance with the field of science raised in the study. Discussion results and seminars are used to improve the deficiencies (negative cases) of research results.

\section{Fishbond diagrams of Communicative Competence}

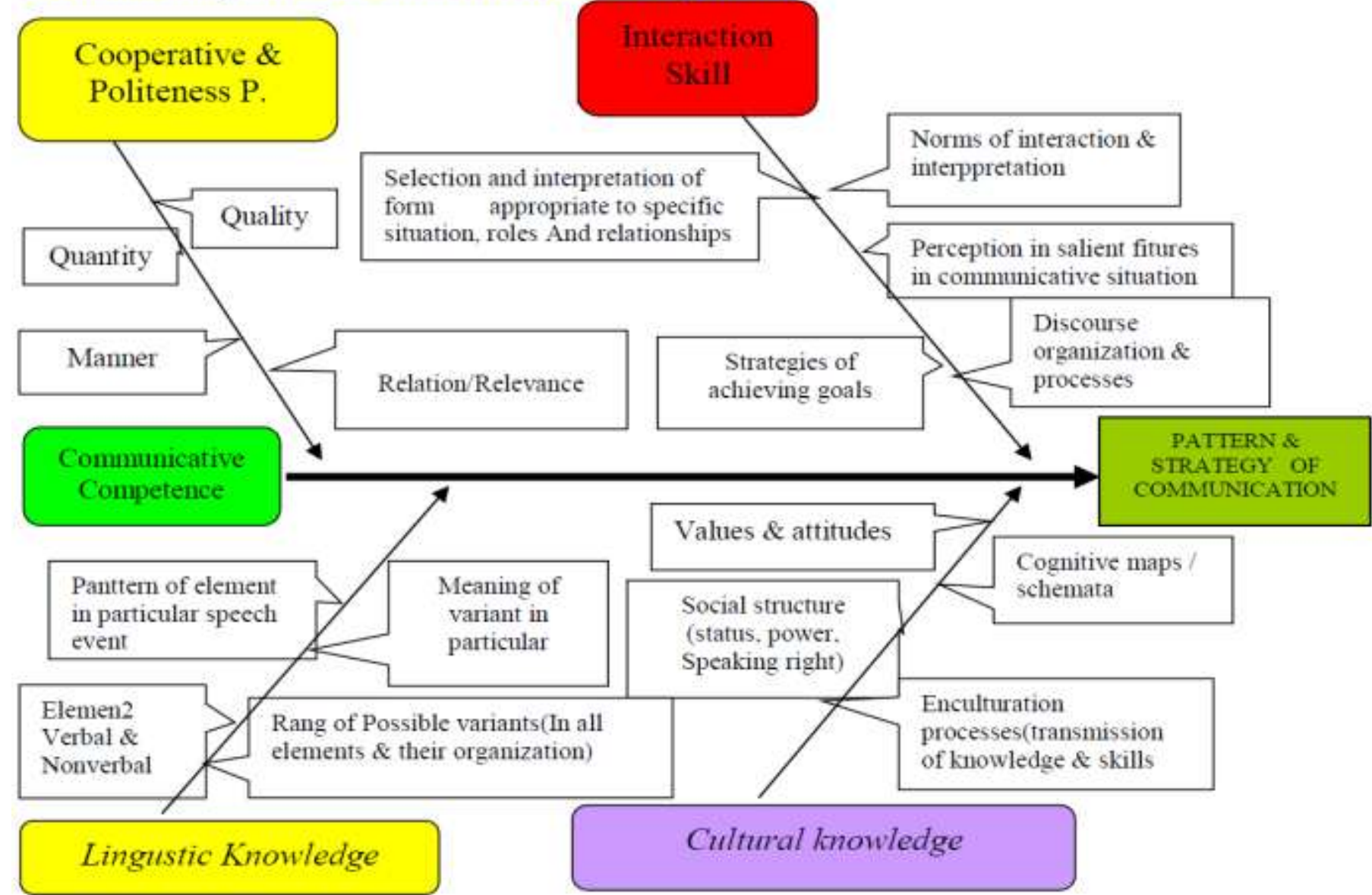




\section{Finding and Discussion}

\section{Communicative Competence in Melayokaken Tradition}

Communicative Competence is the ability of the speaker and hearer in conveying the message by considering many language code, what to say to whom, and how to say it correctly in certain situations involving social knowledge and culture which the speakers and participants have said so that the purpose of speech can be delivered well without reaping the issues.

Communicative competence is very important owned by every participant said because the success of communication is determined by the communicative competence owned by someone. Communicative competence held by the perpetrators of tradition melayokaken and those involved in it can be broken down as follows:

\section{Languistic Knowledge possessed by the people involved in melayokaken tradition}

It can not be denied that the language is used to perform many of the functions of communication, but the function of the language of the most essential is to convey information. Lyons (1972: 32); Brown and Yule (1996: 2) argue that simple communication can be used to express feelings, moods, and attitudes to others. Therefore, more precise communication is defined as the deliberate delivery of factual or proportional information. Thus, communication is the attempt of the speaker/writer to convey something to the listener/reader or have him do something (Haryono, 2014).

Therefore, it is very important for every human being involved in communication to possess linguistic knowledge because without linguistic mastery someone will be isolated in speech community. The linguistic knowledge of the actors of melayokaken and those involved in the tradition is undoubted since they were born in the midst of a strong Using citizen with the use of language and culture of Using, although they were pointed out as Javanese and speakers of the Javanese dialect Using. Whatever the outside community claims about Banyuwangi Using community (BUC), in reality they have their own language and culture that are typical and different from Javanese language and culture in general.

This is reflected in the verbal and nonverbal elements they exhibit in communicating. They use Using language in their daily activities as well as in certain events such as religious rituals, traditional ceremonies, formal and informal meetings involving Using citizens, especially in the act of communication in order melayokaken. They can use Using language well and correctly, both verbally and non verbally shown by the symbols seen from the body language.

The pattern of linguistic elements used by melayokaken actors reflected in speech events is in accordance with the context of speech, so that can be accepted and understood well by participants said. This shows that the pattern of language usage in the context of certain speech in accordance with the corridor that has been determined in the use of language of Using as one of the language used in the community said BUC, so that the speech can be digested well by the opponent said.

The range of language variants used in all elements and the organization of those elements is well applied so that the meanings of the language variants used in situations and contexts can be well understood by all participants in the melayokaken tradition. This language mastery is seen in the following speech data.

Data 1: Conversation of the parent's side (PS) with the prospective daughter-in-law (DI)

PS:Kelendi nduk, wes siap siro? Sore wes diomonge Bambang?

(How are you, are you ready? Yesterday afternoon, did Bambang tell you?)

DI:Yo Mak, wes mateng rencanane.

(Yes mother, the plan is well done)

PS: Yo ayo wes...

(Yes, let's do that)

The speech happens when a man's aunt will flee the girl, at the request of her nephew. Participants of speech who coincidentally from the ethnic Javanese speakers of the Javanese language of Using dialect have no difficultise in communicating with the language and dialect so that both parties understand each other what they mean in the communication. The purpose of the utterance in the conversation above is to make sure the girl wants and is ready to be carried away. This can be seen from the saying Kelendi $n d u k$, wes siap siro?' (How are you, are you ready?). It emphasizes the girl's readiness to be sacked (rushed). Answer the girl 'Yo Mak, wes mateng rencanane' (Yes Mother, the plan is well done). It shows that the girl is really ready to run. This indicates that conversations with the men are well understood. This also means that the mastery of the linguistic knowledge is undoubted in their competence.

The form and the content of the message (act sequence) is a conversation whose contents follow up the previous conversation between the male candidate and the girl in order to perform melayokaken which turned out to show the readiness of the girl to be abducted. Tone of speech (key) that is used the girl's lower than the tone that is used by PS as an older person. The use of a lower tone that the girl uses as a form of respect to a future aunt-in-law. It also shows that the girl understand the principles of communication strategy that is the politeness principle. It is also an indicator of mastery of linguistic principles (linguistic knowledge).

The speech tools (instrumentalities) that is used in the conversation are spoken language without loudspeakers because the two sides are close together. In fact, the conversation is a secret thing that no one else can hear.

As a form of use of interaction norms in the conversation the girl uses a lower-level speech than her aunt's candidate as a tribute to an older person. However, in order not to reduce the familiarity both use the Java language of Using dialect is level ngoko. In addition, both have the same social status in Using societies.

Interaction Skill Used by The People Involved in 


\section{Akhmad Haryono / Communicative Competence in Mlayokaken Tradition of Banyuwangi "Using" Community}

\section{Melayokaken Tradition}

In oral communication skills of interaction is also not less important than the mastery of language because language mastery without being followed by a good interaction skills can also cause communication failure. A person who has good mastery of interaction can help achieve the goal of speech. In fact, with the mastery of good interaction a person can make participants say more interested in communicating. Therefore, a communicator is necessary and important to master the interaction in communicating.

Interaction skills practiced by actors involved in melayokaken traditions can be categorized well. This can be seen from the results of participant observation that shows that perception of important features in communicative situation has been achieved well. This is evident from the interaction practiced by speakers who are seen in accordance with the spoken language used and the purpose of speech that becomes the ultimate target of communication. The ability of interaction can also be seen from the understanding of speech participants who can receive well every communicative purpose communicated.

Applying selection and interpretation of appropriate forms for specific situations, roles, and relationships in the rules for speech use also shows good competence. This can be seen from the language used by the colok that does not cause noisy in the family of the women, and even managed to solve the problems that occur between families after the melayokaken event. Therefore, there is no known violation of interaction norms in the conversation. It shows that the strategy to achieve the goal of speech is well achieved. As illustrated in the following data.

Data 2: Conversations between colok/messenger (M) and Family Party of the Woman/Parents (P)

M: Pak, sepuntene! kulo ngriki ajenge nyanjange, yuga ndika setri diplayokaken lare jaler so griyo kulo dibeto teng griyo lare jaler niku, kula saksine. Ajenge dirabi, kepundi tangge ndika?

(Sir, I'm sorry, I'm here to tell you, your daughter is abducted by the boy from my house to the boy's house, I witnessed that he will marry her, what do you think?)

P: Empun kedadosan makaten, nggeh kula serahaken ndika, hang penting didamel sae. Sa'lanjute kula nyuwun tulung kale ndika diurusi griyane pundi, kula manut mawon kale ndika.

(This is the case, I submit to you fully, which is important to be made good, then I ask you where his house, I just surrender to you)

The situation of conversation above happened at woman's house, after the girl was rushed. At that time at the house the women were very busy because the brothers and the neighbors came to show a sense of sorry for the escort of the girl to the house of the men.

Participants said besides the colok and the women's parents were also witnessed by close relatives and the neighbors who mostly consist of BUC as a form of support to the women. Therefore, they all already understand the existence of melayokaken tradition that just happened, so most of the participants said tolerant and all who attend did not make the atmosphere moody, but even soothing atmosphere. As the statement from one of the attendees who he is still the victim's relatives as follows:

Ya wes...wes kedadian ngene ijek areppe nyapo, hang nglakone wes pdha senenge, hang penting dibuat baik-baik.

(Yes already .... It's been happening like this, what to do next, they love each other, the important thing is for goodness).

The data shows that within the tradition of Using people, abducting a girl for getting married has become a tradition that has long been performed. Thus, the number of participants said not to be the cause of more complicated problems that occur.

As for the purpose of saying on data 2, first of all as a representative of the women's party apologized for the melayokaken case of girl. Secondly, appealed to the woman's family opinion about the next step to be taken after her daughter was rushed off. The purpose of the speech is well understood by the women, so all the problems are left to the colok to be mediated on how best to do next.

The form and the content of the message (act sequence) is a conversation that contains mediation between the men and women who done by colok. For that, be careful in doing the mediation to avoid a murky atmosphere. This is indicated by the speech tone (key) used by the lower colok of the tone used by the female parent. This is to express the guilt of the man who has escaped the girl. It also means that colok is as a trusted person could be a mediator between the family and the problems of the women actually had a good interaction skill to achieve the speech goal.

The instrument used to solve the problem is oral language without loudspeakers because the two sides are close together and relatives and neighbors all listen to the conversation between the two parties. With good spoken language both sides can understand and respect each other's arguments.

As a form of use of interaction norms, in the conversation use the level of speech krama inggil (high speech levels) as a form of respect colok to the parents of the women. Similarly, the parents of the female party use the same level of speech as a form of respect to the guests. With mutual respect both parties avoid the situation that leads to conflict between speakers.

\section{Cultural Knowledge and Its Application in Melayokaken Tradition}

The intrinsic relationship of language and culture is well known. It is seen from the management of communicative behavior and cultural system, which is a very important relationship in the development of general theory of communication, and the description and analysis of communication in a specific speech community. The concept of cultural evolution depends on the human ability to use language for the purpose of organizing social cooperation (Saville-Troike, 2003: 27-28; Haryono, 2015: 33).

There is a correlation between the form and content of the 


\section{Akhmad Haryono / Communicative Competence in Mlayokaken Tradition of Banyuwangi "Using" Community}

language with the current beliefs, values, and needs in the culture of the speakers. The vocabulary of the language gives us a catalog of things that are important to community, which is an index for speakers to categorize experiences they've had before-and often a record related to their past and culture. Grammar can show how time is segmented and organized according to their beliefs about the power of living beings and social categories that are important in the culture (SavilleTroike, 2003: 28; Haryono, 2015: 33)

The social structure in a community is a part of the culture of a society that determines when and how language is used. Social structure can be determined by social status, role, position, age difference, gender, and family ties. There are values and norms that have become conventions in certain speech societies, especially the people of Using related to the application of language in different social structures in society. The application of language in different social structures is reflected in the attitude or behavior of the language used by the participants so that it can be seen how the cognitive scheme of each participant speaks in his speech. The process of enculturation through the transmission of knowledge and language skills and the application of culture is an unavoidable necessity in the use of language in a speech society.

In relation to the cultural knowledge, the melayokaken actors have competence and good understanding, but in its application it is difficult to be performed by speech participants. This happens because the participants said more priority to the purpose of speech in melayokaken ie want to speed up the process of marriage so that there was a violation of the norms and conventions adopted by the Using community. The tradition of melayokaken is a shortcut to a legitimate marriage to the exclusion of parents because they are deemed not to bless the relationship of both to marry. In general, the perpetrators actually know that his actions violate the values and norms that have become conventions in the speech community.

As Bambang's statement, a melayokaken actor from Singojuru Banyuwangi "he did know that what he is doing is not in accordance with the values and norms adopted by Moslem Using community, but to accelerate the process of marriage valid according to our religion through this melayokaken shortcut. He is finally approved".

Statement on the above data indicates that the violation is actually done to seek the blessing of parents, because by melayokaken wedding process will be accelerated and will get the blessing of parents. The following conversation data is a description of the violation of the values and norms of the Using community convention.

Data 3: Conversation of Perpetrators of Melayokaken

Boy:Serehne mak aji heng agree riko oleh ison, klendi enake? Riko gelem ta ison pelayokaken?

(Because mak Aji does not agree that I marry you, which is better? Are you ready I abduct you?)

Girl: Iyo, weh opo jare rico

(Yes, already up to you)

Girl: Kadung gedigu, iSun negotiations hulung ambi keluargane iSun
(If so, I want to talk it first with my family)

Boy : family isun setuju deck, myane cepet riko kesuk bengi dijuwut ambi kerabate isun hurry.

(My family agrees, to be soon tomorrow night you will be taken away by my family (secretly)

Girl : Iyo wes..

(Yes, it's already ...)

Situation/setting (situation, place, and atmosphere) is outside the girl's house for fear the conversation is known to parents. Participants say consists of the youth as the person who took the initiative to perform melayokaken and the girl who is the person who will be abducted. The purpose of the speech is to invite the girl to do melayokaken. The form of the message conveyed in the form of questions that the actual content to seek approval of the girl. Both are trying to use low-pitched tone and voice to avoid or anticipate the conversation being known by others. Therefore, they do not use any speech utensils except by the spoken language which is clarified by the sign language (body language).

In the above conversation data 3 has observed the interaction norms for the opponent of speech. This is evident from the use of Tanya's sentence patterns reflected in the phrase Serehne mak aji heng agree riko oleh ison, klendi enake? Riko gelem ta ison pelayokaken? (If you do not agree with me, how good would it be? You want me to run?). Pattern of the sentence questioned as an indication that speakers use the principles of politeness in inviting the opponent said (the girl). Nevertheless, for mak aji as a third person (the girl's parents) these sentences have violated the norms of modesty to the parents, in the absence of an attempt to convince parents to give their blessing to both. It also indicates a violation of cultural values and norms for $\underline{U} \operatorname{sing}$ community.

\section{Conclusion}

Communicative competence held by actors and persons involved in melayokaken can be categorized well. This is evident from the linguistic knowledge, interaction skill, and cultural knowledge in the process of melayokaken. The perpetrators and the people involved consisted of a young man carrying a run, a girl being rushed, a woman's parent, a male parent, and a colok having no obstacles in communicating. In fact, colok have a pattern and a powerful communication strategy in communicating with women's parent. This is evident from the completion of the problems of both parties after the arrival of the colok which is the envoy of the men.

However, the conspiracy perpetrated by the actors and those involved in the process melayokaken violates the values and cultural norms adopted by the Banyuwangi Using community. This is evident from the behavior of the language performed by the youth, the girl, the men, and the colok who have no desire to ask permission and negotiation efforts with the women by utilizing the colok as a person who is believed to solve the problem with a powerful communication strategy .

\section{Acknowledgement}

Thank you very much to Rector of University of Jember, Dean of Faculty of Culture Science, University of Jember, and 
Akhmad Haryono / Communicative Competence in Mlayokaken Tradition of Banyuwangi “Using” Community

DRPM Ministry of Research Technology and Higher Education Indonesia for the support and assistance of this research realization.

\section{References}

[1] Bleicher, J. 1982. "System and Meaning: Comments on the Work of Niklas Luhmann" in Theory Culture \& Society, First Published February 1, 1982, https://doi.org/10.1177/026327648200100105

[2] Brown, G. \& Yule, G. 1996. Analisis Wacana. Diindonesiakan oleh I. Soetikno, Jakarta: PT Gramedia Pustaka Utama.

[3] Douglas, D. J. 1970. Understanding Everyday Life, Chicago: Aldine Pub. Co.

[4] Geertz, C. 1973. The Interpretation of Cultures. NEW YORK: Basic Books, Inc., Publishers

[5] Haryono, A. 2018. "Communication Patterns Among Kiais Of Nahdlatul Ulama In The Madurese Ethnic Group" in Indonesian Journal of Applied Linguistic (IJAL) Vol 7, No 3, Januari 2018, p.714-726

[6] 2017. "The Tradition of Melayokaken in Using Society: The Causal Factors and Its Impacts".in Humaniora: Journal of Culture, Literature, and Language, Vol.29, No. 1 2017: 37-45.

[7] 2015. Etnografi Komunikasi: Kosep, Teori, Metode, dan Contoh Penelitian Pola Komunikasi, Jember: Jember University Press.

[8] . 2014. "Penceritaan Kisah Ulama/Kiai Dalam Tuturan Sebagai Pola dan Strategi Penyampaian Pesan Warga Nahdlatul Ulama Etnik adura", in Humaniora: Journal of Culture, Literature, and Language, Volume 26 No. 3 Oktober 2014, Halaman 123-136, Yogyakarta: FIB UGM.

[9] Garfinkel, H. 1967. "Studies in Ethnomethodology". http://www.citeulike .org/ group/ 890/author/Garfinkel:H. diakses tanggal 27 Juli 2018

[10] Grice, H.P. (1975). "Logic and Conversation", in Cole dan Morgen. Radical Pragmatics. New York: Akademic Press, pp. 41-58.

[11] Hymes. D. 1972b. “On Cmmuninicative competence”. In J.B. Pride \& J. Holmes (eds.) Socolinguistics. Harmondswort: Penguin.

[12]__ 1982b. "Postface".in Hymes. 1982a. Vers la competence de communicatin. Trans. by F. Mugler. Paris: Hatir Credif.

[13]Ibrahim, Abd. Syukur.1994. Panduan Penelitian Etnografi Komunikasi. Surabaya: Usaha Nasional.

[14] Kusnadi. (1993)., "Santet dalam Pandangan Orang Using", in Surya, 11 september

[15] Kuswarno, E. (2008). Etnografi Komunikasi: Suatu Pengantar dan Contoh Penelitiannya. Bandung: Widya Padjadjaran.

[16] Lyon, J. 1972. "Human Language”. In R.A. Hinde (ed.) Non Verbal communication. Cambridge: Cambridge University Press.

[17] Marwoto, dkk. 1999. Kajian Hermeneutik Mantra Using Banyuwangi, Jember: Laporan Penelitian, Jember: Lemlit
Universitas Jember.

[18] Marwoto dan Saputra, H. S.P. 2000. Mantra Using: Sabuk Mangir (SM) dan Cekek Gambiran (CG). Jember: Laporan Penelitian, Jember: Lemlit Universitas Jember.

[19] Saputra, H. S.P. 2007. Memuja Mantra Sabuk Mangir dan Jaran Goyang Masyarakat Suku Using Banyuwangi. Yogyakarta: LKiS

[20] Sariono, A. (2007). Pemilihan bahasa dalam masyarakat Using: Studi kasus pada masyarakat Using di Kelurahan Singotrunan, Kecamatan Banyuwangi, Kabupaten Banyuwangi. (Unpublished Ph.D. Dissertation) Universitas Gadjah Mada, Yogyakarta: UGM

[21] Saville-Troike, M. 2003. Ethnographi of Communication: an Introduction. New York: Basil Blackwell Inc.

[22] Schiffrin, D. 1994. Aproaches to discourse.Cambridge, Massachusetts 02142 USA: 108 Cowley Road Oxford OX4 1Jf UK

[23] Sentot, H. A. 1995. Basanan dan Wangsalan sebagai Kritik Sosial: Tinjauan Awal terhadap Sastra Lisan di Banyuwangi”. In Warta ATL: Jurnal Pengetahuan dan Komunikasi Peneliti dan Pemerhati Tradsi Lisan. Vol. 1 No. 1. hlm. 45-50.

[24] Sudjarwadi, dkk. 1995, Struktur Sastra Lisan Using Banyuwangi, Laporan Penelitian Jember:Lemlit Universitas Jember.

[25] Sugihartoyo. 1993. Tinjauan Karakteristik, Motivasi, dan Peranan Santet di Kabupaten Banyuwangi, Sebagai Upaya Memberikan Pertimbangan Dimasukkan dan Tidaknya dalam KUHP Nasional. Makalah Seminar Fakultas Hukum Universitas 17 Agustus 1945 Banyuwangi.

[26] Yule, G. 1998. Pragmatics. Hongkong: Oxford University Press. 